\title{
Extension of the postharvest life of 'Pollock' avocado using modified atmosphere packaging
}

Chamara Kumari Illeperuma*, Chamilani Nikapitiya

Department of Food Science \& Technology,

Faculty of Agriculture,

University of Peradeniya, Sri Lanka

chamarai@mail.pdn.ac.lk
${ }^{*}$ Correspondence and reprints

Received 19 October 2001 Accepted 11 May 2002

Fruits, 2002, vol. 57, p. 287-295 (C) $2002 \mathrm{Cirad} /$ EDP Sciences All rights reserved

DOI: $10.1051 /$ fruits:2002025

RESUMEN EsPAÑol, p. 295

\section{Extension of the postharvest life of 'Pollock' avocado using modified atmosphere packaging.}

Abstract - Introduction. The postharvest life of 'Pollock' avocado, a popular cultivar grown in Sri Lanka, is 7-10 d at room temperature. A short postharvest life limits its export volume by sea freight. Materials and methods. Pollock avocado fruit were packaged in $0.05 \mathrm{~mm}$ thick low-density polyethylene (LDPE) bags to create a modified atmosphere (MA), and they were stored at $12{ }^{\circ} \mathrm{C}$ and $94 \%$ relative humidity. The effect of the potassium permanganate, an ethylene absorber, and of the granular charcoal, a carbon dioxide absorber, on modifying the in-package atmosphere was tested. During storage, carbon dioxide, oxygen and ethylene contents were measured. The packages were opened after MA storage, and the fruit ripened naturally under ambient conditions. The weight loss, changes in firmness, total soluble solids (TSS), pulp color, visual quality rating (VQR), chilling injury index (CI) and disease index (DI) during or after storage were determined. Results. Compared with the samples packaged without absorbers, those packaged with absorbers had significantly lower carbon dioxide and ethylene contents. MA packaging was effective in extending the postharvest life of Pollock avocado up to $17 \mathrm{~d}$. Inclusion of absorbers further extended the postharvest life up to $29 \mathrm{~d}$. Firmness, TSS, pulp color, VQR, CI and DI of the ripened fruits were not significantly affected by the MA conditions. Discussion. The MA conditions did not alter the ripening process and were successful in preventing the chilling injury and diseases. Packaging of Pollock avocado in $0.05 \mathrm{~mm}$ LDPE bags at $1: 1$ surface to weight ratio $\left(\mathrm{cm}^{2} \cdot \mathrm{g}^{-1}\right)$ with ethylene and carbon dioxide absorbers and storing at $12{ }^{\circ} \mathrm{C}$ and $94 \%$ relative humidity can be recommended to extend their storage life up to $29 \mathrm{~d}$

Sri Lanka / Persea americana (fruits) / introduced varieties / keeping quality / controlled atmosphere storage

\section{Prolongation de la vie après-récolte de l'avocat 'Pollock' par conditionnement sous atmosphère modifiée.}

Résumé - Introduction. La vie après-récolte de l'avocat 'Pollock', un cultivar couramment cultivé au Sri Lanka, est de (7 à 10) j à la température ambiante. Cette courte durée de vie limite les possibilités d'exportation par le fret maritime. Matériel et méthodes. Des avocats Pollock ont été emballés dans des sacs de polyéthylène à basse densité de $0,05 \mathrm{~mm}$ d'épaisseur (PEBD) pour créer une atmosphère modifiée (AM), et ils ont été stockés à $12{ }^{\circ} \mathrm{C}$ et $94 \%$ d'humidité relative. L'effet du permanganate de potassium, absorbeur d'éthylène, et de grains de charbon de bois, absorbeurs de gaz carbonique, sur la modification de l'atmosphère à l'intérieur des sacs a été évalué. Les teneurs en $\mathrm{CO}_{2}, \mathrm{O}_{2}$ et éthylène ont été mesurées pendant le stockage. Les sacs ont été ouverts après stockage sous AM, et le fruit a mûri naturellement en condition ambiante. La perte de poids, les changements de fermeté, la teneur en sucres solubles totaux (SST), la couleur de pulpe, l'estimation visuelle de la qualité (EVQ), les dommages liés à la réfrigération (DR) et un index de maladie (IM) pendant ou après stockage ont été déterminés. Résultats. Comparés aux échantillons emballés sans absorbeurs, ceux emballés avec absorbeurs ont eu une teneur en $\mathrm{CO}_{2}$ et $\mathrm{O}_{2}$ sensiblement inférieure. La mise sous AM a prolongé la vie après récolte des avocats jusqu'à $17 \mathrm{j}$. L'ajout d'absorbeurs a permis de la prolonger jusqu'à $29 \mathrm{j}$. La fermeté, la teneur en SST, la couleur de pulpe, l'EVQ, les DR et l'IM des fruits mûrs n'ont pas été sensiblement affectés par les conditions d'AM. Discussion. L'utilisation d'AM n'a pas eu d'effet sur le processus de maturation et elle a permis d'empêcher les dommages liés à la réfrigération et aux maladies. L'emballage de l'avocat Pollock dans des sacs de PEBD de $0,05 \mathrm{~mm}$ d'épaisseur [rapport de surface/poids de $1: 1\left(\mathrm{~cm}^{2} \cdot \mathrm{g}^{-1}\right)$ ], avec des absorbeurs d'éthylène et de $\mathrm{CO}_{2}$, stockés à $12{ }^{\circ} \mathrm{C}$ et $94 \%$ d'humidité relative, peut être recommandé pour prolonger leur durée de stockage jusqu'à $29 \mathrm{j}$.

Sri Lanka / Persea americana (fruit) / variété introduite / aptitude à la conservation / stockage en atmosphère contrôlée 


\section{Introduction}

Among the 220 cultivars of avocado in the world, the West Indian cultivars are best suited for the tropics. Most cultivars grown at present in Sri Lanka are of a seedling origin. The Department of Agriculture introduced to Sri Lanka and recommended 'Pollock', a West Indian cultivar; 'Gottfried', a hybrid between Mexican and West Indian races; and 'Purple hybrid' [1]. Nevertheless, other cultivars have also been introduced recently: 'Fuerte', a hybrid between Mexican and Guatemalan cultivars; 'Booth 7', a hybrid between Guatemalan and West Indian cultivar; and 'Simmonds', a West Indian cultivar [2].

Small quantities of avocado are exported by air freight from Sri Lanka, mainly to the Maldives, Hong Kong, Singapore and the Middle Eastern countries. The total quantities of avocado exported in 1993, 1997 and 1998 were $(1590,1296$ and 1021) kg, respectively [3]. Air freight being an expensive mode of transportation, sea freight of avocado could be possible if measures were taken to delay ripening and prevent diseases such as stem end rot and anthracnose, and, thereby, to extend storage life.

Modified atmospheres (MA) are created when fruits are sealed in packages made of polyethylene films with relatively low permeability to gases. As fruit respire, the oxygen level decreases and carbon dioxide level increases, thereby reducing the rate of respiration and delaying the climacteric ethylene rise $[4,5]$. MA packaging must be combined with low temperature storage to further extend shelf life. However, avocado is sensitive to chilling injury (CI) at low temperatures. The recommended storage temperature for cultivars of West Indian origin is $13^{\circ} \mathrm{C}$ and, for Guatemalan and Mexican cultivars is ( 4 and 8$)^{\circ} \mathrm{C}$, respectively [6]. Extension of the postharvest life has been reported at $5^{\circ} \mathrm{C}$ in $30 \mu \mathrm{m}$ polythene bags for 'Hass' avocado, a Guatemalan cultivar [7], and at ( 4 to 7.5 ) ${ }^{\circ} \mathrm{C}$ in polythene bags of $0.05 \mathrm{~mm}$ thickness for 'Fuerte', a Mexican-Guatemalan hybrid, and for 'Hass' [8]. However, there are no studies on MA storage of West Indian avocado cultivars that require a higher storage temperature than Guatamalan and Mexican cultivars.

This study describes the development of a modified atmosphere packaging system to extend the storage life of 'Pollock' avocado at $12{ }^{\circ} \mathrm{C}$ and $94 \%$ relative humidity. The effect of MA conditions on the visual quality of the fruit was studied. The effectiveness of ethylene and carbon dioxide absorbers in further extending the storage life was also tested.

\section{Materials and methods}

\subsection{Preliminary experiment}

Pollock avocado fruit were obtained from the Gannoruwa research farm (long. $7^{\circ}$ $17^{\prime} \mathrm{N}$, lat. $80^{\circ} 34^{\prime} \mathrm{E}$ ). Two hundred and fifty uniformly mature disease-free fruits with the stalk were selected for the study. Twenty-five fruits were randomly selected and allowed to ripen under ambient conditions. The firmness of the fruit was measured daily as described below, using three fruits at a time, to find out the fruit firmness after ripening that is acceptable to the palate. Twenty fruits were randomly selected and analysed in triplicate for firmness, pulp color and total soluble solids (TSS) to find out their biological variability and maturity, and the data were tested using the Student's $t$ test.

The stalks were trimmed to $1 \mathrm{~cm}$ length, and the fruit washed in 1:5 dilution of a commercial bleach (Chlorox) at 5.25\%. The stem end of the fruit was dipped in $0.1 \%$ benomyl for $1 \mathrm{~min}$ and air-dried before storage. Low-density polyethylene (LDPE) bags of two thicknesses, $0.05 \mathrm{~mm}$ and $0.075 \mathrm{~mm}$, provided by Varna Ltd., Ratmalana, a leading packaging manufacturer in Sri Lanka, were used to create modified atmospheres. Eighteen packages each of $0.05 \mathrm{~mm}$ LDPE, and $0.075 \mathrm{~mm}$ LDPE, containing three fruits were used for the study. Ethylene and carbon dioxide absorbers, made as described below, were kept in nine packages of each packaging material.

The experimental treatment was a twofactor factorial $(2 \times 2)$ with $0.05 \mathrm{~mm} \mathrm{LDPE}$ 
and $0.075 \mathrm{~mm}$ LDPE as the levels of one factor and presence and absence of absorbers as the levels of the second factor laid out in a completely randomised design. Self-sealing septa were fixed onto the packages to facilitate gas measurements, and the packages were stored at $12{ }^{\circ} \mathrm{C}$ and $94 \%$ relative humidity for $21 \mathrm{~d}$. Three packages from each treatment combination were used to measure in-package concentrations of carbon dioxide, oxygen and ethylene and to record the chilling injury (CI) index, visual quality rating (VQR) and disease index (DI) at weekly intervals as described below.

\subsection{Preparation of absorbers}

A saturated solution of potassium permanganate $(50 \mathrm{~mL})$ was absorbed onto individual clay bricks $(9 \mathrm{~cm} \times 4.5 \mathrm{~cm} \times 4.5 \mathrm{~cm})$, dried at $80{ }^{\circ} \mathrm{C}$ until the surface of the brick was completely dry, and bagged in $20 \mu \mathrm{m}$ thick high density polyethylene for use as ethylene absorbers. Granular charcoal (2 g) wrapped with muslin cloth was used as a carbon dioxide absorber.

\subsection{Main experiment}

Based on in-package concentrations of oxygen and carbon dioxide, $0.05 \mathrm{~mm}$ LDPE was selected for the main experiment. The oxygen, carbon dioxide and water vapour permeability rates of the material were $0.03 \mathrm{~mL} \cdot \mathrm{m}^{-2} \cdot \mathrm{h}^{-1} \cdot \mathrm{atm}^{-1}, 0.16 \mathrm{~mL} \cdot \mathrm{m}^{-2} \cdot \mathrm{h}^{-1} \cdot \mathrm{atm}^{-1}$ and $195 \mathrm{~g} \cdot \mathrm{m}^{-2} \cdot \mathrm{h}^{-1} \cdot \mathrm{atm}^{-1}$, respectively. The selection, treatment and preparation of fruits for storage and storage conditions were as in the preliminary experiment. Three fruits and the absorbers were kept in each 24 LDPE bag lapproximately $(41 \mathrm{~cm} \times$ $4 \mathrm{~cm}$ )] of $1: 1$ surface to weight ratio $\left(\mathrm{cm}^{2} \cdot \mathrm{g}^{-1}\right)$ and the packages were sealed. Another set of 24 LDPE bags containing three fruits and a wrapped brick without potassium permanganate were sealed. The packages with and without absorbers were used in a completely randomised design; in-package concentrations of carbon dioxide, oxygen, ethylene and physical properties such as weight loss and firmness were determined in triplicate from day 14 in storage, at 3-d intervals.
Three perforated LDPE packages ( 12 holes of $1.96 \times 10^{-3} \mathrm{~cm}^{2}$ per $100 \mathrm{~cm}^{2}$ ), containing three fruits in each, were prepared and stored at $12{ }^{\circ} \mathrm{C}$ and $94 \%$ relative humidity. The concentrations of oxygen, carbon dioxide and ethylene in the perforated packages were measured at 3-d intervals starting from day zero. Initiation of the ripening process was noted by observing textural changes as felt when pressed softly with the thumb.

\subsection{Determination of optimum storage and quality of ripened fruits}

Thirty packages each with and without absorbers and fifteen perforated packages (control) were stored at $12{ }^{\circ} \mathrm{C}$ and $94 \%$ relative humidity. Each package contained three fruits. The packages subjected to MA storage were opened after $(15,17,19,21,23$, 25, 27, 29 and 31) d. The control packages were opened after $(8,10,12,14$ and 16) $d$. The fruits were allowed to ripen naturally under ambient conditions until fruit firmness was between $(0.75$ and 0.70$) \mathrm{kg} \cdot \mathrm{cm}^{-2}$, and the ripened fruits were observed for the visual quality rating (VRQ) and the disease index (DI). The optimum storage period was determined based on the VQR and DI. The firmness, TSS, $\mathrm{pH}$, and pulp color of the ripened fruits subjected to the MA storage for an optimum period were determined as described below and compared with the control fruits.

\subsection{Gaseous composition}

In-package concentrations of oxygen, carbon dioxide and ethylene were measured using a gas chromatograph (Shimadzu, model GC-14B, Tokyo, Japan). For the oxygen measurement, a molecular sieve column, a thermal conductivity detector, helium carrier gas at a flow rate of $40 \mathrm{~mL} \cdot \mathrm{min}^{-1}$, and column, injector and detector temperatures of $(50,90 \text { and } 110)^{\circ} \mathrm{C}$, respectively, were used. The carbon dioxide was measured using a Poropak Q column, and the conditions were the same as for oxygen. For the ethylene measurement, a Poropak Q column, a flame ionisation detector, nitrogen carrier gas at a flow rate of $70 \mathrm{~mL} \cdot \mathrm{min}^{-1}$, and column, injector and 
detector temperatures of $(65,100$ and 120) ${ }^{\circ} \mathrm{C}$, respectively, were used.

\subsection{Physicochemical properties}

Each sample was weighed before packaging and after opening, and the weight loss percentage was calculated. The firmness of the fruits was measured by taking the force $(\mathrm{kg})$ required to penetrate $1 \mathrm{~cm}$ using a fruit firmness tester (AST Everwell Co., Tokyo, Japan). Pulp color was measured by using a color difference meter (ZE 2000 Nippon Denshuku, Tokyo, Japan). TSS was measured on finely cut flesh tissue $(5 \mathrm{~g})$ homogenised with $5 \mathrm{~mL}$ of distilled water using a mortar and pestle. The mortar and pestle were washed twice with $5 \mathrm{~mL}$ each of distilled water. The pooled solutions were centrifuged (Kokushan H-1500 F, Tokyo, Japan) at $6000 \mathrm{~g}$ for $10 \mathrm{~min}$. The TSS of the supernatant was measured using a hand-held refractometer (Atago, model PR-1, Tokyo, Japan).

\subsection{Chilling injury index, visual quality rating and disease index}

The chilling injury (CI) index of the mesocarp appearing as grey discoloration was evaluated visually using a 1-4 scale: 1 , no discoloration; 2, light grey discoloration in not more than $30 \%$ of the pulp; 3 , light grey discoloration in more than $30 \%$ of the pulp; and 4 , severe dark to black discoloration. The CI was calculated according to the method of Meir et al. [7].

The visual quality rating (VQR) and the disease index (DI) were assessed by observing the fruit peel as follows. VQR: 1, nonedible; 3, edible, cannot be sold; 5, fair, defects moderate; 7, good, slight defects; 9 , excellent, and DI: 0, no disease; 1 , (1 to $10) \%$ disease; 2 , (11 to 20$) \%$ disease; 3 , (21 to 30$) \%$ disease; $4,31 \%$ and over disease.

\subsection{Statistical analyses}

The CI, VQR and DI were analysed by the Friedman's test using the MINITAB statistical package. The data on the in-package gaseous composition and physicochemical properties of the fruit during storage were subjected to variance analysis using the SAS package [9], and the means were compared at $p<0.05$ according to the Fisher's protected Least Significant Difference test. The physicochemical data obtained for ripened fruits were analysed using ANOVA, and the means were separated using the Duncan's Multiple Range Test.

\section{Results and discussion}

\subsection{Preliminary experiment}

The Student's $t$ test performed on firmness, TSS and pulp color data revealed that the biological variability and maturity among 20 fruits were not significant at $p<0.05$. Fruit firmness after ripening varied between $(0.70$ and 0.75$) \mathrm{kg} \cdot \mathrm{cm}^{-2}$. [Packaging material $\times$ absorber] interaction effects were significant $(p<0.05)$ on in-package concentration of carbon dioxide and subjective measurements on the VQR, DI and CI. The main effects, packaging material and absorber, were significant $(p<0.05)$ on in-package concentrations of oxygen and ethylene, respectively. The concentration of carbon dioxide was significantly lower $(p<0.05)$ in packages of $0.05 \mathrm{~mm}$ thickness with absorbers than in packages of $0.075 \mathrm{~mm}$ thickness with or without absorbers (table I). The concentration of oxygen was significantly higher $(p<0.05)$ in packages of $0.05 \mathrm{~mm}$ thickness than in packages of $0.075 \mathrm{~mm}$ thickness. The concentration of ethylene was significantly lower $(p<0.05)$ in packages containing absorbers than in those without absorbers (table I).

The maximum tolerable carbon dioxide concentration of $8 \%$ and the minimum tolerable oxygen concentration of $2-3 \%$ have been reported for most fruits and vegetables [10]. A thickness of $0.05 \mathrm{~mm}$ was more suitable than that of $0.075 \mathrm{~mm}$ for packaging of Pollock avocado as the concentration of carbon dioxide was below and oxygen was above the injury levels (table I). Moreover, the VQR and DI of fruits stored 
in $0.05 \mathrm{~mm}$ LDPE bags were significantly better $(p<0.05)$ than those stored in $0.075 \mathrm{~mm}$ LDPE bags with or without absorbers (table II).
Development of chilling injury during storage of certain avocado cultivars below $13{ }^{\circ} \mathrm{C}$ has been reported [6]. The significantly higher $(p<0.05)$ CI index observed

\section{Table I.}

In-package concentrations of oxygen, carbon dioxide and ethylene during storage of 'Pollock' avocado in ( 0.05 and 0.075 ) $\mathrm{mm}$ low-density polyethylene bags (LDPE) packages, with and without absorbers at $12{ }^{\circ} \mathrm{C}$ and $94 \%$ relative humidity.

\begin{tabular}{|c|c|c|c|c|c|c|}
\hline \multirow[t]{2}{*}{ Days in storage } & \multicolumn{2}{|c|}{ Oxygen (\%) } & \multicolumn{2}{|c|}{ Carbon dioxide (\%) } & \multicolumn{2}{|c|}{ Ethylene $\left(\mu \mathrm{L} \cdot \mathrm{L}^{-1}\right)$} \\
\hline & $\begin{array}{c}\text { LDPE } \\
(0.05 \mathrm{~mm})\end{array}$ & $\begin{array}{c}\text { LDPE } \\
(0.075 \mathrm{~mm})\end{array}$ & $\begin{array}{c}\text { LDPE } \\
(0.05 \mathrm{~mm})\end{array}$ & $\begin{array}{c}\text { LDPE } \\
(0.075 \mathrm{~mm})\end{array}$ & $\begin{array}{c}\text { LDPE } \\
(0.05 \mathrm{~mm})\end{array}$ & $\begin{array}{c}\text { LDPE } \\
(0.075 \mathrm{~mm})\end{array}$ \\
\hline \multicolumn{7}{|l|}{ With absorbers } \\
\hline 7 & 3.6 & 2.1 & 4.9 & 7.3 & 0.7 & 0.9 \\
\hline 14 & 3.2 & 2.1 & 5.1 & 16.4 & 1.1 & 1.2 \\
\hline 21 & 3.1 & 2.1 & 5.4 & 12.9 & 1.0 & 2.9 \\
\hline \multicolumn{7}{|c|}{ Without absorbers } \\
\hline 7 & 4.2 & 2.1 & 7.8 & 7.3 & 21.0 & 8.8 \\
\hline 14 & 5.2 & 2.1 & 8.8 & 16.4 & 9.5 & 14.2 \\
\hline 21 & 4.0 & 2.1 & 7.7 & 13.0 & 21.3 & 20.8 \\
\hline $\mathrm{LSD}_{0.05}$ & \multicolumn{2}{|c|}{0.7} & \multicolumn{2}{|c|}{2.6} & \multicolumn{2}{|c|}{3.0} \\
\hline
\end{tabular}

Table II.

Visual quality rating (VQR), disease index (DI) and chilling injury index (CI) of 'Pollock' avocado during storage in $(0.05$ and 0.075$) \mathrm{mm}$ low-density polyethylene bags (LDPE) packages with and without absorbers at $12{ }^{\circ} \mathrm{C}$ and $94 \%$ relative humidity.

\begin{tabular}{|c|c|c|c|c|c|c|}
\hline \multirow[t]{2}{*}{ Storage in days } & \multicolumn{2}{|c|}{$\operatorname{VQR}(1-9)^{1}$} & \multicolumn{2}{|c|}{ DI $(0-4)^{2}$} & \multicolumn{2}{|c|}{$\mathrm{Cl}(1-4)^{3}$} \\
\hline & $\begin{array}{c}\text { LDPE } \\
(0.05 \mathrm{~mm})\end{array}$ & $\begin{array}{c}\text { LDPE } \\
(0.075 \mathrm{~mm})\end{array}$ & $\begin{array}{c}\text { LDPE } \\
(0.05 \mathrm{~mm})\end{array}$ & $\begin{array}{c}\text { LDPE } \\
(0.075 \mathrm{~mm})\end{array}$ & $\begin{array}{c}\text { LDPE } \\
(0.05 \mathrm{~mm})\end{array}$ & $\begin{array}{c}\text { LDPE } \\
(0.075 \mathrm{~mm})\end{array}$ \\
\hline
\end{tabular}

$\begin{array}{ccccccc}\text { With absorbers } & & & & & \\ 7 & 9 & 9 & 0 & 0 & 1 & 1 \\ 14 & 9 & 5 & 0 & 1 & 1 & 2 \\ 21 & 9 & 1 & 0 & 4 & 1 & 3\end{array}$

\begin{tabular}{|c|c|c|c|c|c|c|}
\hline \multicolumn{7}{|l|}{ Without absorbers } \\
\hline 7 & 9 & 9 & 0 & 0 & 1 & 1 \\
\hline 14 & 9 & 5 & 0 & 1 & 1 & 2 \\
\hline 21 & 7 & 2 & 0 & 3 & 1 & 3 \\
\hline Probability value & & & & & & \\
\hline
\end{tabular}


for fruits stored in $0.075 \mathrm{~mm}$ LDPE bags than for those stored in $0.05 \mathrm{~mm}$ LDPE bags with or without absorbers (table II) reveals that Pollock avocado could be stored at $12{ }^{\circ} \mathrm{C}$ in $0.05 \mathrm{~mm}$ LDPE bags without developing chilling injury. Ten percent of the fruit stored without absorbers ripened after $14 \mathrm{~d}$ of storage and the rest ripened in $21 \mathrm{~d}$ of storage. The fruit stored with absorbers did not ripen during storage for $21 \mathrm{~d}$. Therefore, the effect of absorbers on further extension of storage life was tested in the main experiment.

\subsection{Main experiment}

Atmospheres containing 2-6\% oxygen and $3-10 \%$ carbon dioxide have been shown to be effective in inhibiting softening and reducing chilling injury of avocado in controlled atmosphere (CA) [5, 11, 12] and MA $[7,8,13]$ storage conditions at $(5$ and 7$){ }^{\circ} \mathrm{C}$.
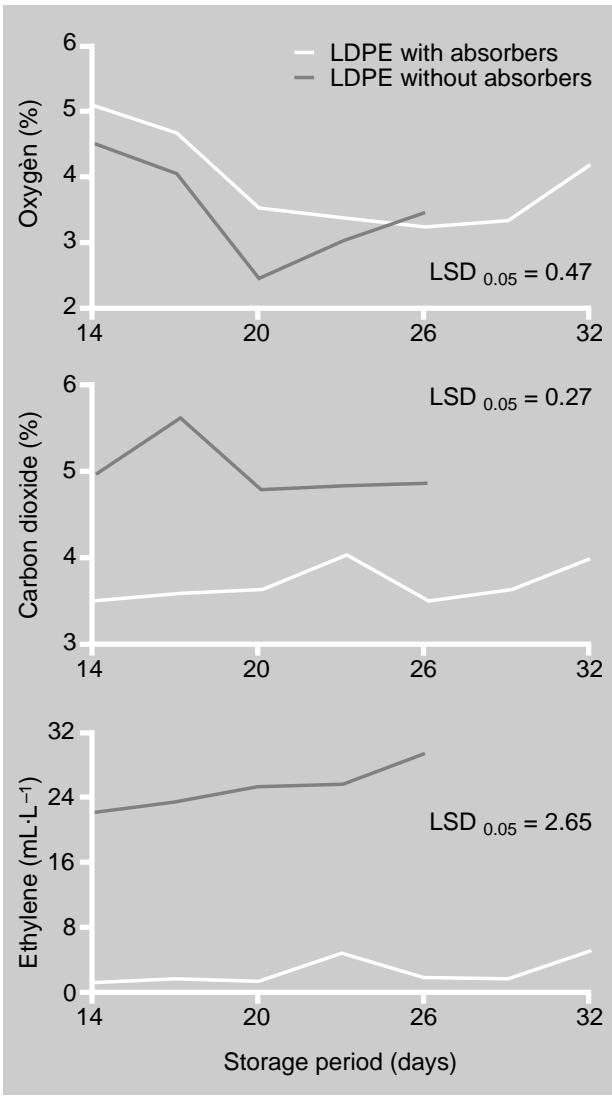

The in-package oxygen and carbon dioxide concentrations varied from (5.7 to 3.4)\% and (3.5 to 3.7$) \%$, respectively, during the storage from day 14 to 29 in $0.05 \mathrm{~mm}$ LDPE bags with absorbers (figure 1). The oxygen concentrations varied from (4.5 to 2.4 )\% and carbon dioxide concentrations varied from (5.0 to 4.8$) \%$ in packages without absorbers during storage from day 14 to 20 . These values were significantly different from those in packages with absorbers ( $f i g$ ure 1). Carbon dioxide being a product of the respiratory process, a decrease in respiration rates of several fruits has been reported with an increase in the in-package carbon dioxide concentration [14-16]. Under low oxygen and high carbon dioxide atmospheres, delaying the ethylene climacteric rise, decreasing the respiration rate and retarding of ripening and deterioration processes of avocado fruits have been reported $[4,5]$. Ethylene concentrations varied from (1.6 to 1.8$) \mu \mathrm{L} \cdot \mathrm{L}^{-1}$ from day 14 to 29 in packages with absorbers and from $(24$ to 27$) \mu \mathrm{L} \cdot \mathrm{L}^{-1}$ from day 14 to 20 in packages without absorbers (figure 1). This difference indicates that potassium permanganate absorbed onto clay bricks is effective in absorbing in-package ethylene and thereby delaying ripening, as indicated by the significantly higher $(p<0.05)$ firmness of the fruit packaged with ethylene absorbers than those packaged without ethylene absorbers (figure 2). Maintenance of avocado fruit quality $[11,17]$ and reducing the chilling sensitivity of avocado fruits under low ethylene levels have been reported [18]. The significantly higher VQR at $p<0.05$ of the ripened fruits subjected to MA storage with absorbers than those without absorbers (table III) may be due to the lower accumulated levels of ethylene during storage of the former than the latter ( $f$ igure 1). The scores obtained for the CI and DI revealed that MA storage at $12{ }^{\circ} \mathrm{C}$ was successful in preventing diseases and chilling injury of Pollock avocado fruits. Low oxygen and high carbon dioxide concentrations developed inside the packages may have prevented development of anthracnose. Similar results were reported for 'Fuchs' and 'Waldin' avocado cultivars subjected to CA storage in 2\% oxygen and 10\% carbon dioxide for 3-4 weeks [19]. 
The percentage weight loss of the fruit stored with absorbers was significantly lower than that of the fruit stored without absorbers (figure 2). This may be due to a higher rate of metabolic activities of the fruit stored without absorbers than of those stored with absorbers. The firmness of the fruits stored in bags with ethylene absorbers did not change significantly from day 14 to 29 , and was significantly higher than those stored without absorbers from day 14 to 20 (figure 2). This may be due to inhibition of the expression of hydrolytic enzymes associated with avocado fruit softening under low oxygen and high carbon dioxide conditions [20]. High accumulated levels of ethylene in the packages without absorbers (figure 1) may have increased pectin methylesterase activity [11, 21], thereby making the fruit softer than those packaged with absorbers (figure 2).

The oxygen concentration in the perforated bags was $20.5 \pm 0.3 \%$ during the storage and concentrations of carbon dioxide and ethylene were not detectable. The fruit kept in perforated LDPE bags and stored at $12^{\circ} \mathrm{C}$ ripened in $12 \mathrm{~d}$. All the fruit packaged in $0.05 \mathrm{~mm}$ LDPE without absorbers ripened in $25 \mathrm{~d}$ in storage. The scores for the VQR for fruits ripened after storage for (17 and 19) d without absorbers were 9 and 5 , respectively, and, for the DI, the scores were 0 and 1 , respectively. Similar scores were obtained for fruits ripened after stor-

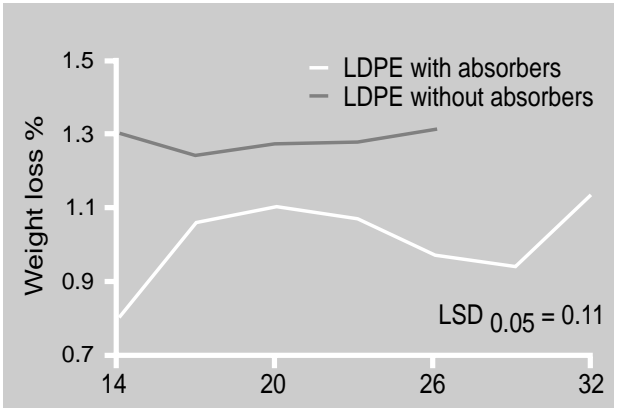

Figure 2.

Percentage of weight loss and firmness of avocados on day 14-32 in storage at $12^{\circ} \mathrm{C}$. Each point represents three replications (LDPE $=$ low density polyethylene). Initial firmness was $1.9 \mathrm{~kg} \cdot \mathrm{cm}^{-2}$.

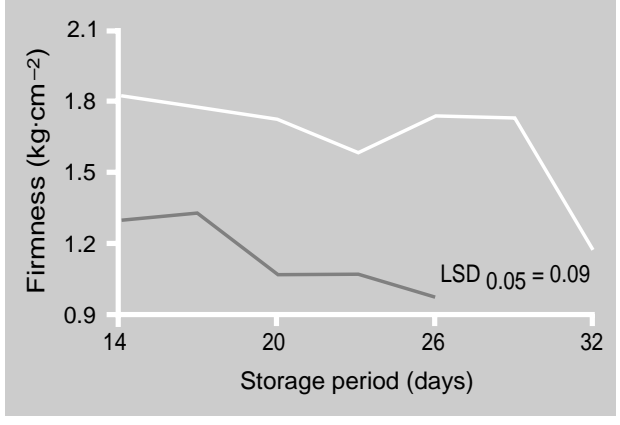

age for (29 and 31) d in packages with absorbers. Thus, the optimum storage period of the samples packaged in LDPE bags without and with absorbers, as based on the VQR and DI, was (17 and 29) d, respectively, and, for the control fruits, this optimum period was $12 \mathrm{~d}$. Extension of the postharvest life of 'Hass' avocado at $5{ }^{\circ} \mathrm{C}$ under MA conditions up to 9 weeks has been reported [7]. In this present study, the extension of the postharvest life up to $29 \mathrm{~d}$

Table III.

Physicochemical properties of ripe 'Pollock' avocado after storage under different conditions at $12{ }^{\circ} \mathrm{C}$ and $94 \%$ relative humidity.

\begin{tabular}{|c|c|c|c|c|}
\hline Storage condition & $\begin{array}{l}\text { Storage period } \\
\text { (d) }\end{array}$ & $\begin{array}{l}\text { Firmness } \\
\left(\mathrm{kg} \cdot \mathrm{cm}^{-2}\right)\end{array}$ & $\begin{array}{l}\text { Total soluble solids } \\
\text { ( }{ }^{\circ} \text { Brix) }\end{array}$ & $\begin{array}{l}\text { Pulp color } \\
\text { 'b' value }\end{array}$ \\
\hline Perforated LDPE ${ }^{1}$ & 12 & 0.75 & 6.0 & 5.4 \\
\hline LDPE without absorbers & 17 & 0.72 & 6.1 & 5.1 \\
\hline LDPE with absorbers & 29 & 0.70 & 6.8 & 5.6 \\
\hline Test significance & ns & ns & ns & ns \\
\hline Duncan critical value & & 0.19 & 1.14 & 0.96 \\
\hline
\end{tabular}


at $12{ }^{\circ} \mathrm{C}$, at which the rates of the metabolic activities are higher than than at $5^{\circ} \mathrm{C}$, could be sufficient to sea freight the commodity. Fruit stored with absorbers versus without absorbers ripened within 3-4 d and 1-2 d, respectively, when removed from the bags. The firmness, TSS content and pulp color of the fruit subject to MA storage with and without absorbers were similar to those of the fruit that were not subjected to MA storage (table III). This similarity shows that the ripening process was not impaired by the MA conditions. Thus, packaging of Pollock avocado in $0.05 \mathrm{~mm}$ LDPE bags at 1:1 surface to weight ratio $\left(\mathrm{cm}^{2} \cdot \mathrm{g}^{-1}\right)$ with potassium permanganate and granular charcoal and storage at $12{ }^{\circ} \mathrm{C}$ and $94 \%$ relative humidity can reduce postharvest losses. The suitability of this method to extend the postharvest life of recently introduced cultivars in Sri Lanka, such as 'Fuerte', 'Booth 7' and 'Simmonds' needs to be studied.

\section{Acknowledgements}

The authors are thankful to Dr. R.O. Thattil, Professor, Faculty of Agriculture, University of Peradeniya, for his help with statistical analyses, and Mr. L. Wawegama, Technical Officer, Faculty of Agriculture, University of Peradeniya, for his help with gas analyses. The study was supported by a grant from the National Science Foundation of Sri Lanka (Grant Number: RG/96/AG/02).

\section{References}

[1] Mankotte K.N., Avocado, Publ. Dep. Agric., Minist. Agric., Land For., Sri Lanka, 1996, pp. 2-3.

[2] Anonymous, Exports, External trade statistics, Dep. Sri Lanka Cust., Stat. Div., Colombo, Sri Lanka, 1998, pp. 416-419.

[3] Anonymous, Expert consultation on avocado production development in Asia and the Pacific Food and Agriculture Organisation of the United Nations, Reg. Off. Asia Pac., FAO Rep., Bangkok, Thailand, April 27-29, 1999, pp. 8-9.

[4] Biale J.B., Effect of oxygen concentration on respiration of the 'Fuerte' avocado fruit, Am. J. Bot. 33 (1964) 363-373.
[5] Meir S., Akerman M., Fuchs Y., Zauberman G., Further studies on the controlled atmosphere storage of avocados, Postharvest Biol. Technol. 5 (1995) 323-330.

[6] Salunkhe D.K., Desai B.B., Avocado, in: Postharvest biotechnology of fruits, Vol. II, CRC Press, Florida, USA, 1984, pp. 27-38.

[7] Meir S., Naiman D., Akerman M., Hyman J.Y., Zauberman G., Fuchs Y., Prolonged storage of 'Hass' avocado fruit using modified atmosphere packaging, Postharvest Biol. Technol. 12 (1997) 51-60.

[8] Scott K.J., Chaplin G.R., Reduction of chilling injury in avocado stored in sealed polythene bags, Trop. Agric. (Trinidad) 55 (1978) 87-90.

[9] Anonymous, SAS/STAT User's Guide, Version 6, Forth edition, SAS Institute Inc., Cary, North Carolina, USA, 1994, pp. 229-234.

[10] Day B.P.F., Effective packaging for fresh produce, in: Ackermann P., Jagerstad M., Ohlsson T. (Eds.), Foods and packaging materials: chemical interactions, The Royal Society of Chemistry, Cambridge, UK, 1997, pp. 89-100.

[11] Hatton T. Jr., Reeder W.F., Quality of 'Lula' avocados stored in controlled atmospheres with or without ethylene, J. Am. Soc. Hortic. Sci. 97 (1972) 339-341.

[12] Barmore C.R., Rouse A.H., Pectinmethylesterase activity in controlled atmosphere stored avocado, J. Am. Soc. Hortic. Sci. 100 (1976) 294-296.

[13] Gonzales G., Yahia E.M., Higuera I., Modified atmosphere packaging (MAP) of mango and avocado fruit, Acta Hortic. 269 (1990) 335-344.

[14] Kader A.A., Biochemical and physiological basis for effects of controlled and modified atmospheres on fruits and vegetables, Food Technol. Chicago 40 (1986) 99-100, 102-104.

[15] Kerbel E.L., Kader A.A., Romani R.J., Effect of elevated carbon dioxide concentrations on glycolysis in intact 'Barlett' pear fruit, Plant Physiol. 86 (1988) 1205-209.

[16] Li C., Kader A.A., Residual effects of controlled atmosphere on postharvest physiology and quality of strawberries, J. Am. Soc. Hortic. Sci. 115 (1989) 975-978.

[17] Zauberman G., Fuchs Y., Ripening process in avocados stored in ethylene atmosphere in cold storage, J. Am. Soc. Hortic. Sci. 98 (1973) 477-480.

[18] Lee S.K., Young R.E., Temperature sensitivity of avocado fruit in relation to $\mathrm{C}_{2} \mathrm{H}_{4}$ treatment, J. Am. Soc. Hortic. Sci. 109 (1984) 689-692. 
[19] Spalding D.H., Reeder W.F., Low-oxygen high-carbon dioxide controlled atmosphere storage for control of anthracnose and chilling injury of avocados, Phytopathology 65 (1975) 458-460.

[20] Kanellis K., Solomos T., Mattoo A.K., Hydrolytic enzyme activity and protein pattern of avocado fruit ripened in air and in low oxygen, with and without ethylene, Plant Physiol. 90 (1989) 257-266.

[21] Gertman E., Fuchs Y., Changes in pectinmethylesterase (PME) activity caused by ethylene applied at different temperatures, Plant Cell Physiol. 15 (1974) 501-505.

\section{Prolongación de la vida post-cosecha del aguacate 'Pollock' mediante acondicionamiento en atmósfera modificada.}

Resumen - Introducción. La vida post-cosecha del aguacate 'Pollock', un cultivar muy cultivado en Sri Lanka, es de (7 a 10) d a temperatura ambiente. Esta breve duración de vida limita las posibilidades de exportación por flete marítimo. Material y métodos. Se envasaron aguacates Pollock en bolsas de polietileno de baja densidad de $0,05 \mathrm{~mm}$ de grosor (PEBD) para crear una atmósfera modificada (AM) y se almacenaron a $12{ }^{\circ} \mathrm{C}$ y $94 \%$ de humedad relativa. Se evaluó el efecto del permanganato de potasio, absorbente de etileno, y de granos de carbón de madera, absorbentes de gas carbónico, en la modificación de la atmósfera dentro de las bolsas. Se midieron los contenidos de $\mathrm{CO}_{2}, \mathrm{O}_{2}$ y etileno durante el almacenamiento. Se abrieron las bolsas, después del almacenamiento en AM y el fruto maduró naturalmente en condición ambiente. Se determinaron la pérdida de peso, los cambios de firmeza, el contenido de azúcares solubles totales (AST), el color de la pulpa, la estimación visual de la calidad (EVC), los daños relacionados con la refrigeración (DR) y el índice de enfermedad (IE) durante o después del almacenamiento. Resultados. Si se comparan las muestras envasadas sin absorbentes con las envasadas con absorbentes, éstas últimas tuvieron un contenido de $\mathrm{CO}_{2}$ y $\mathrm{O}_{2}$ sensiblemente inferior. La colocación en AM prolongó la vida post-cosecha de los aguacates hasta $17 \mathrm{~d}$. La adición de absorbentes permitió prolongarla hasta $29 \mathrm{~d}$. La firmeza, el contenido de AST, el color de la pulpa, la EVC, los DR y el IE de las frutas maduras no se vieron sensiblemente afectados por las condiciones de AM. Discusión. La utilización de AM no tuvo efecto sobre el proceso de maduración y permitió impedir los daños relacionados con la refrigeración y las enfermedades. El envase del aguacate Pollock en bolsas de PEBD de 0,05 $\mathrm{mm}$ de grosor [relación de superficie/peso de $1: 1\left(\mathrm{~cm}^{2} \cdot \mathrm{g}^{-1}\right)$, con absorbentes de etileno y $\mathrm{CO}_{2}$, almacenados a $12{ }^{\circ} \mathrm{C}$ y $94 \%$ de humedad relativa, puede recomendarse para prolongar su duración de almacenamiento hasta 29 d.

Sri Lanka / Persea americana (fruto) / variedades naturalizadas / aptitud para la conservación / almacenamiento atmósfera controlada

To access this journal online: www.edpsciences.org 